\title{
Revalidation of the Concept of Rakthasaarata with Reference to Treatment Response in Iron Deficiency Anaemia
}

\section{Ragesh C ${ }^{1}$, Ajitha.K ${ }^{2}$, Anjali Sivaram ${ }^{3}$.}

${ }^{* 1}$ Assisstant Professor, Dept. of Kriyasareera, PNNM Ayurveda M edical College, Cheruthuruthy, Thrissur, Kerala State, India.

${ }^{2}$ Associate Professor, Dept. of Kriyasareera, Govt Ayurveda college, Kannur, Kerala State, India.

${ }^{3}$ Assistant Professor, Dept. of Kriyasareera, Govt Ayurveda college, Kannur, Kerala State, India.

\section{ABSTRACT}

Background: Saara is considered as an important concept of Ayurveda, which is responsible for assessing strength \& stability. The concept of saarata is a good mirror to assess properties and function of dhatus. Balaof specific dhatuwill be increased as per his saara. Rakthasaara assessment can be done with the tools developed from classical references and some objective parameters. With this, scoring for rakthasaarata can be done in anaemia patients. This score can be compared with haemogram at various stages of the treatment to look for any association. If the high rakthasaarata score patient gets better treatment response, it indicates that the treatment schedule can be modified according to the saarataof the individual.

Objective: To assess the influence of rakthasaarata in treatment response of iron deficiency anaemia.

Materials and M ethods: 30 patients were selected with $\mathrm{Hb}$ range $7-11.9 \mathrm{~g} / \mathrm{dl}$ and serum ferritin level less than $20 \mu \mathrm{g} / \mathrm{L}$. After the selection their saara assessment was done. Based on the saara score they were divided into 3 groups (saara score 24-29 $1^{\text {st }}$ group;30-35 $2^{\text {nd }}$ group and 36-41 $3^{\text {rd }}$ group).Thenpatients were advised to take vyoshaditakra for a period of 45 days. Full haemogram test was done in $1^{\text {st }}, 15^{\text {th }}, 30^{\text {th }}, 45$ th days for getting response.Serum Ferritin was assessed on $1^{\text {st }}$ and $30^{\text {th }}$ day.

Results: At the end of this study it is noticed that the effect of intervention on $\mathrm{Hb}, \mathrm{RBC}, \mathrm{WBC}, \mathrm{Platelet}, \mathrm{MCHC}, \mathrm{MCH}$, PCV etc was significant in group 1 and 3. But the changes in group 1 values were obtained mostly after the total course of intervention while significant changes were noticed in group 3 even in the middle of intervention i.e. changes noticed in different phases of intervention.

Conclusion: Individual with better rakthasaarascore, get faster response to the treatment of iron deficiency anaemia.

KEY WORDS: Saara, Rakthasaara, Iron deficiency anemia, Vyoshaditakra, Haemogram, Serum ferritin.

Address for correspondence: Dr. Ragesh C, Assisstant Professor, Dept of Kriyasareera, PNNM Ayurveda M edical College, Cheruthuruthy, Thrissur, Kerala State, India.

E-Mail: rageshpgi@gmail.com

\begin{tabular}{|c|c|c|}
\hline \multicolumn{3}{|c|}{ Online Access and Article Informtaion } \\
\hline \multirow{2}{*}{ Quick Response code } & \multicolumn{2}{|c|}{$\begin{array}{l}\text { International Journal of Integrative Medical Sciences } \\
\text { www.imedsciences.com }\end{array}$} \\
\hline & $\begin{array}{l}\text { Received: 14-07-2016 } \\
\text { Reviewed: 14-07-2016 }\end{array}$ & $\begin{array}{l}\text { Accepted: 19-07-2016 } \\
\text { Published: 31-07-2016 }\end{array}$ \\
\hline Source of Funding: Self & \multicolumn{2}{|c|}{ Conflicts of interest: None } \\
\hline
\end{tabular}

\section{BACKGROUND}

Ayurveda, gives knowledge about maintenance of physical and mental health. Physical foundations or basic elements of the body are dosha, dhatu and mala [1]. For a healthy living, precise balance should be maintained in the body between these basic elements. Among these one important factor is dhatu "dharanatdhatava" [1] refers to the basic nutritional and structural aspect of body maintaining a state of dynamic metabolic 
equilibrium in normal state. These are seven in number each of them acts as a pillar in the body, as the function of each dhatu is dharana (to support) and poshana(to nourish).

The excellence in functioning of a dhatu is an indicator of the competence of the human body. Saarapariksha forms an integral part of examination of an individual, based on which the treatment modality should be planned [2]. Saaralakshanahave been described in our classics for each of the seven dhatu andtheir evolution helps in assessing the state of the functioning of these dhatu in the body.

In Ayurveda Sara pareeksha is one among the most useful examination for the purpose of Rogipareeksha, it has wide range of application in this science. Even it has wide range of possibilities at the level of application, the sarapareeksha is not properly studied yet.

Rakthasaara assessment can be done with the tools developed from classical references and some objective parameters. With this, scoring for rakthasaarata can be done in anaemia patients. This score can be compared with haemogram at various stages of the treatment to look for any association. If the high rakthasaarata score patient gets better treatment response, it indicates that the treatment schedule can be modified according to the saarataof the individual.

\section{MATERIALS AND METHODS}

Patients approached the hospital based on the advertisement are advised for haemogram. 30 patients with $\mathrm{Hb}$ range $7-11.9 \mathrm{~g} / \mathrm{dl}$ and serum ferritin level less than $20 \mu \mathrm{g} / \mathrm{L}$ were selected [1]. After the selection, their saara assessment was done. Based on the saara score they were divided into 3 groups (saara score 24-29 $1^{\text {st }}$ group; 30-35 $2^{\text {nd }}$ group and 36-41 $3^{\text {rd }}$ group). Thenpatients were advised to take vyoshaditakra for a period of 45 days. The follow up assessment was done on $15^{\text {th }}$ day and repeated on $30^{\text {th }}, 45$ th days for getting response. Ferritin test was done on $1^{\text {st }}$ and $30^{\text {th }}$ day. Full haemogram test was done in $1^{\text {st }}, 15^{\text {th }}, 30^{\text {th }}, 45^{\text {th }}$ days.

To check serum ferritin, Fully Automated Bidirectionally Interfaced Chemi Luminescent Immuno Assay (C.L.I.A) was used. To evaluate
$\mathrm{Hb}, \mathrm{DC}$, WBC count, RBC count, PCV, MCV, MCH, $\mathrm{MCHC}, \mathrm{RDW}$, Platelet count, BC-3000 plus Auto Hematology Analyzer was used. For correcting iron deficiency anemiaVyoshadiTakra was given.Vyoshaditakra is a preparation mentioned in sahasrayoga for the treatment of panduroga .Vyoshaditakra is made as $12 \mathrm{gm}$ of vyoshadichoorna mixed with $96 \mathrm{ml}$ of takra [1]. Close the mouth of the vessel and keep it for a night. Care must be taken to use earthen pots for fermentation of milk and to keep the drug. The next day morning it is filtered. Now the drug is ready for use and it is taken in early morning before food. This preparation is known as vyoshaditakra.

Questionnaire for assessing saarawas prepared on the basis of cardinal sara features, as explained by AcharyaCharaka1 and Susruta². Thus a total of 37 features were obtained for the assessment of rakthasaarata. Considering the practical difficulty for assessment, the features pertaining to genital organ were not included in the preparation of pro forma, 29saarafeatures were taken into consideration.

The details of these 29 sara features

1. Unctous, reddish and charming with radiant appearance of ears

2. Unctous, reddish and charming with radiant appearance of eyes

3. Unctous, reddish and charming with radiant appearance of face

4. Unctous, reddish and charming with radiant appearance of tongue

5. Unctous, reddish and charming with radiant appearance of nose

6. Unctous, reddish and charming with radiant appearance of lips

7. Unctous, reddish and charming with radiant appearance of the sole and palm

8. Unctous, reddish and charming with radiant appearance of nails

Psychological characters

9. Sukham-happiness

10. M anaswitvam - enthusiasm

11.Klesaasahishnutvam -intolerance to discomfort

12. Ushnaasahishnutvam -intolerance to heat

13. Uddhatammedha - great genius 
SaaraAssessment method: Physical features were evaluated by physical examinations.Every physical feature based on its degree i.e. high, moderate, slight, absent, was given score as 3 , $2,1,0$ respectively. Psychological features of subjects were evaluated by interrogation and also by analyzing their behavior at the time of interrogationand fulfillment of questionnaire. The happiness of the individuals was assessed based on the ladder scale for happiness. M ini mental state examination was utilized for the assessment of intelligence.

\section{RESULTS}

There is a positive correlation between Ferritin and saara score. This indicates that value of ferritin corresponds to rakthasaara score. The statistical analysis was done with ANOVA, analysis showed that, treatment response of iron deficiency anemia depends on rakthasaara score; individuals with better rakthasaara score get faster response to the treatment of iron deficiency anemia.

There was significant and gradual increase in mean $\mathrm{Hb}$ value in all the three groups.

There was significant and gradual increase in mean ferritin value in all the three groups.

There was gradual increase in mean RBC count in all the 3 groups, the changes were significant in group 1 and group3

There was significant and gradual increase in mean WBC count in all the three groups

There was gradual increase in mean Neutrophil value in all the 3 groups; the changes were significant in group 1 and group3.

There was gradual increase in mean Lymphocyte value in group 1 and group 3; the changes were significant in group 1 and group3.

There was gradual increase in mean Platelet count in all the 3 groups; the change was significant in group 1 and group3.

There was significant and gradual increase in mean $\mathrm{MCHC}$ value in all the 3 groups.

There was gradual increase in mean MCV value in all the 3 groups; the change was significant only in group 3.

\section{DISCUSSION}

Main objective of this study is to assess the influence of rakthasaarata in the treatment response of iron deficiency anaemia. At the end of this study it is noticed that the effect of intervention on $\mathrm{Hb}, \mathrm{RBC}, \mathrm{WBC}$, Platelet, $\mathrm{MCHC}$, $\mathrm{MCH}, \mathrm{PCV}$ etc was significant in group 1 and 3 . But the changes in group 1 values were obtained mostly after the total course of intervention while significant changes were noticed in group 3 even in the middle of intervention i.e. remarkable changes in these parameters could be noticed in different phases of intervention. Hence it can be assumed that the third group that is, who had better rakthasaarata got better treatment response. Because in the third group, i.e who had better rakthasaara the rakthadhatwagni, ranjaka pitta as well as the concerned srotas is in better condition as saara is an indicator of quantitative and qualitative perfect dhatu.

This indicates that, treatment response of iron deficiency anemia depends on rakthasaara score. Individual with better rakthasaara score, get quick response to the treatment of iron deficiency anemia. Saara represent excellence of dhatu qualitatively and quantitatively. In the case of rakthasaarata, formation and function of rakthadhatu is in better condition. So in individual with better rakthasaara score, rakthadhatwagni, ranjakapitha and rakthava hasrotas function properly. This will helps in for getting faster treatment response in iron deficiency anemia. The selected drug vyoshadithakra is a rich source of iron. Iron absorption becomes efficient in an acidic medium which is also ensured by thakra in the selected drug. When nutrients are supplemented the conversion of nutrients into poshakadhatu then into sthayidhathu takes place faster rate in better rakthasaara individual due to their better rakthadathwagni condition. According to susrutharanjakapitta is situated in yakrith and pleeha [3]. According to ashtangahridaya it is situated in amasaya [9]. Liver is an important site for production and storage of various materials needed for $\mathrm{Hb}$ formation. Iron is absorbed, transported and stored using the protein apotransferin and apoferritin produced by liver [4]. It is also the site for production of erythropoietin. Spleen is an important site of storage of blood cells, it also possess capacity 
to carry out erythropoiesis in adult life. Functions of Ranjaka pitta can be considered to be above mentioned function of liver and spleen in erythropoiesis. Nutrients for erythropoiesis including proteins, vitamins and minerals are derived from dietary sources. They are absorbed from koshta. The amasayais of great importance for this absorption as the Castles Intrinsic factor is secreted from here. There are different enzymes which regulate hemoglobinformation which can be taken as rakthadhatwagni. So in better rakthasaara individual factors which regulate hemoglobin formation can perform more rapidly.

\section{CONCLUSION}

Treatment response of iron deficiency anaemia depends on rakthasaarascore.Individual with better rakthasaarascore, get faster response to the treatment of iron deficiency anaemia.

\section{Conflicts of interest: None}

\section{REFERENCES}

[1]. Ashtangahridayam with English translation, by prof K.R. SrikanthaM urthy, sutrasthana chapter 11 verse No. 1 and 4, Chowkhamba krishnadas academy 2007, p154

[2]. Charakasamhitha with chakrapanidattas Ayurveda dipika English commentary ,by Dr. Ram karansharma\&vaidyaBhagwanDash,Vimanasthana chapter 8 verse 102,Chowkhamba Sanskrit Series office 2005,p 269

[3]. Harrisons principles of internal medicine $17^{\text {th }}$ edition,Section 2,Hematopoeitic disorders,chapter 98,Mc Graw Hill M edical 2008,p 630

[4]. Sahasrayogam a popular book on keraliya tradition of ayurvedic treatment, with sujana priyavyakhyana by K.V Krishnan vaidya \& S.Gopala pilla,Pandu roga chikithsa, vyoshadi kashaya, Vidyarambham Publication 2013,p 55
[5]. Charakasamhitha with chakrapanidattas Ayurveda dipika English commentary ,by Dr. Ram karansharma\&vaidyaBhagwanDash, Vimanasthana chapter 8 verse 104,Chowkhamba Sanskrit Series office 2005,p 269

[6]. Susruthasamhitha with Dalhanacharya Nibandha samgraha commentary by Acharya P.V. Sharma, suthrasthana chapter 35 , verse 24 , Chowkhamba Orientalia $9^{\text {th }}$ edition 2007,p243

[7]. Susruthasamhitha with Dalhanacharya Nibandhasamgraha commentary by Acharya P.V. Sharma, suthrasthana chapter 21,verse 10, Chowkhamba Orientalia $9^{\text {th }}$ edition 2007,p101.

[8]. Ashtangahridayam with English translation,by prof K.R. SrikanthaM urthy,sutrasthana chapter 12 verse No. 12, Chowkhamba krishnadas academy 2007,p 168.

[9]. Text book of medical physiology by Guyton $\&$ Hall $11^{\text {th }}$ edition, Unit 6,Chapter 32,Elsevier saunders publishers 2006,p 425.

How to cite this article:

Ragesh C, Ajitha.K, Anjali Sivaram. Revalidation of the Concept of Rakthasaarata with Reference to Treatment Response in Iron Deficiency Anaemia. Int J Intg M ed Sci 2016;3(7):369-372. DOI: 10.16965/ijims.2016.142 